\title{
Production of phosphate biofertilizer through composting and vermicomposting process
}

\author{
Ricardo Neves Guimarães', Virgínia Damin², Paulo Marçal Fernandes²,

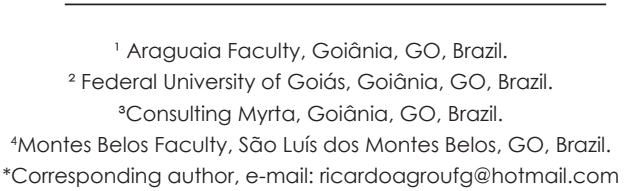
Wilson Mozena Leandro², Aniela Pilar Campos de Melo ${ }^{3}$, Juliano Queiroz Santana Rosa ${ }^{4}$

\begin{abstract}
The production of organic mineral fertilizers enriched with natural phosphates may increase the solubility of phosphorus, minimizing the dependence of acidulated phosphate fertilizers. In view of the above, the objective was to evaluate the bioavailability of nutrients due to the incorporation of phosphate sources through vermicomposting and composting. It was used a completely randomized design in a $4 \times 3$ factorial design, with five replicates and four sources of P (1 - Ammonium single superphosphate, 2 - Itafós phosphate, 3 - Araxá phosphate and 4 - termophosphate) and three methods of phosphorus sources addition in the production of organo-mineral fertilizer process: 1 - Vermicompost produced adding the P sources at the beginning of the vermicomposting process (VPB), 2 - Vermicompost produced adding the P sources at the end of the vermicomposting process (VPE) and 3 - Compound, non-vermicomposting, produced with addition of the $\mathrm{P}$ sources at the beginning of the composting process (CP). The addition of Araxá or Itafós natural phosphate in composting or after vermicomposting process leads to the production of an organo-mineral fertilizer with good availability of nutrients, such as calcium and phosphorus.
\end{abstract}

Keywords: phosphate, earthworms, compost

\section{Introduction}

The association of mineral fertilizers and organic sources is a common practice in agricultural production, titled as organo-mineral fertilization (Kiehl, 2008). This technique adds humus resulting from the decomposition of the organic matter to the minerals, propitiating the formation of fertilizer with high agronomic efficiency. The organic material present in these fertilizers increases the physical, chemical and biological quality of the soil, providing efficient mineral retention and high plant growth (Carvalho et al., 2015).

Integrating vermicomposting and composting technics to natural phosphates can produce organo-mineral fertilizer with high agronomic potential. In vermicompost, earthworms act as shredders of the organic matter, crushing organic waste that passes through their digestive tract, causing physical, chemical and biological changes (Suthar, 2010). The intestinal mucus of these annelids has digestive enzymes and microorganisms that potentiate the mineralization and availability of phosphorus (P).

Composting is characterized by the aerobic action of microorganisms at distinct stages on organic waste. The thermophilic stage occurs at temperatures ranging from 45 to 70 ${ }^{\circ} \mathrm{C}$, allowing the sanitation of organic waste 
and degradation of simple organic structures. The stabilization of the composting occurs in the mesophilic stage, being a time-consuming process, in which degradation of complex organic structures occurs. This stage is important for reducing the phytotoxic potential of the compounds (Kiehl, 2008).

Acidified phosphate fertilizers have been widely used in agriculture, enormous doses of fertilizers have been used, raising the cost of production, in addition, generating wastes that cause serious environmental impacts. Natural phosphates and thermophosphates have great potential for agricultural use, becoming more efficient in acidic environments with $\mathrm{H}^{+}$supply and long cycle cultures (Souza et al., 2007). It should be noted that the world sources of phosphorus are finite and new alternatives must be studied to maximize the availability of phosphorus to the plants.

Therefore, the bioavailability of phosphorus, present in natural phosphates, has been recommended, with vermicomposting and composting processes that may favor the bioavailability of $P$, since they reduce the anionic adsorption of phosphorus by soil clay minerals (Pramanick et al., 2009). The digestion and excretion of organic wastes by earthworms and microorganisms may aid in the process of solubilization of phosphorus and other nutrients (Busato et al., 2012). Thus, the production of organo-mineral fertilizers enriched with natural phosphates can increase the solubility of phosphorus, minimizing the dependence of acidified phosphate fertilizers.

In view of the above, the objective was to evaluate the bioavailability of nutrients due to the incorporation of phosphate sources through vermicomposting and composting.

\section{Materials and Methods}

The experiment was carried out at the Agroecological Training Center of Hidrolândia county $\left(16^{\circ} 3547^{\prime \prime} \mathrm{S}\right.$ and $\left.49^{\circ} 16^{\prime} 47^{\prime \prime} \mathrm{W}, 730 \mathrm{~m}\right)$ from JunetoSeptember2012.Acompletelyrandomized design was used in a factorial scheme $4 \times 3$, with five replicates. The factors evaluated were $P$ sources $(1$ - ammonium single superphosphate, 2 - Itapós natural phosphate, 3 - Araxá natural phosphate and 4 - Yoorin thermophosphate ) and $P$ sources incorporation methods into the organo-mineral fertilizer production process: 1 Vermicompost produced adding the P sources at the beginning of the vermicomposting process (VPB), 2 - Vermicompost produced adding the $P$ sources at the end of the vermicomposting process (VPE) and 3 - Compound, nonvermicomposting, produced with addition of the $P$ sources at the beginning of the composting process (CP). Red California earthworms were used to produce vermicompost (Eisenia foetida Savigny). This species was chosen due to high procreation capacity and conversion of manure to vermicompost. The manure used to produce the vermicompost and compost came from a corral of dairy cattle raised in a semi-extensive management.

Before starting the vermicomposting and composting processes it was necessary to pre-compost the manure. For this purpose, the manure was distributed in a concrete shed, and then it was moistened and homogenized using a hoe. The manure stack was revolved weekly for oxygenation until the stabilization, which occurred 28 days after the beginning of the pre-composting when the material showed dark coloration and absence of odor. By precomposting, the fermentation was eliminated, allowing the colonization of the earthworms aiming the solubilization of the natural phosphates. The chemical characteristics of the manure are described in Table 1.

The chemical analysis of phosphate fertilizers was carried out to quantify the total and available $\mathrm{P}$ content (Table 2) according to Alcarde (2009). For the homogenization of the

Table 1. Chemical characteristics of pre-composted bovine manure.

\begin{tabular}{|c|c|c|c|c|c|c|c|c|}
\hline $\mathrm{pH}$ & C-org & $O M$ & $\mathrm{~N}$ & $P$ & K & $\mathrm{Ca}$ & $\mathrm{Mg}$ & $S$ \\
\hline & - & & 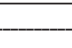 & $-g_{k g}{ }^{-1}$ & - & & & \\
\hline 8.0 & 23.8 & 23.0 & 18.0 & 12.0 & 22.0 & 11.0 & 3.9 & 1.0 \\
\hline
\end{tabular}

C-org = Organic carbon; $\mathrm{OM}=$ Organic Matter. 
phosphorus sources with the pre-composted manure, a rotating drum with a decentralized axis of $80 \mathrm{~kg}$ was used. In this rotating drum 20 $\mathrm{kg}$ of the pre-composted manure and $6 \mathrm{~kg}$ of the respective phosphate sources, ie $23 \%$, were placed. The addition of 2 to $5 \%$ of natural phosphate is recommended to reduce nitrogen losses and increase the level of phosphorus (P2O5) in organic compounds (Campos et al. 2004). In the present work, a higher concentration was used since the objective was to evaluate the phosphorus solubilization.

Table 2. Phosphorus $\left(\mathrm{P}_{2} \mathrm{O}_{5}\right)$ content in the sources used in the vermicomposting and composting process.

\begin{tabular}{lccc}
\hline \multirow{2}{*}{ Sources } & \multicolumn{3}{c}{$\%$} \\
\cline { 2 - 4 } & total $\mathrm{P}_{2} \mathrm{O}_{5}$ & citric acid $\mathrm{P}_{2} \mathrm{O}_{5}$ & water $\mathrm{P}_{2} \mathrm{O}_{5}$ \\
\hline Ammonium single superphosphate & 20.3 & 16.3 & 17 \\
Itapós natural phosphate & 15.3 & 4.7 & 2.1 \\
Araxá natural phosphate & 26.5 & 2.4 & 1.0 \\
Yoorin thermophosphate & 17.5 & 16.0 & 0 \\
\hline
\end{tabular}

After homogenization, the material was distributed in rectangular plots made of masonry lined with plastic canvas $(0.80 \mathrm{~m}$ height $\times 1 \mathrm{~m}$ length $\times 0.70$ widths). Depending on the treatment, each plot received $20 \mathrm{~kg}$ (VPE) or $26 \mathrm{~kg}$ (VPB and CP) of the material. One $\mathrm{kg}$ of earthworms per plot was added, which is about 1,690 earthworms per $\mathrm{kg}$. It was carried out the control of temperature and luminosity for the vermicomposting and the composting aeration. Moisture was maintained at $70 \%$. The plots were covered with raffia bags to prevent earthworm predators attack and loss of moisture.

On the 129 days of the experiment, the earthworms were removed from the vermicompost and weighed. A similar duration time (120 days) was verified by Busato et al. (2102) in a study assessing vermicompost with the addition of natural phosphate. The VPE treatment was carried out by collecting the vermicompost and then adding $6 \mathrm{~kg}$ of the $\mathrm{P}$ sources with subsequent homogenization as previously described. The collected material was homogenized and two samples were taken from each compound and conditioned in a cold chamber at about $5{ }^{\circ} \mathrm{C}$ until the analyses were performed. The chemical attributes (Dry Mass, Carbon, Organic Matter, N, C:N, pH, P, $\mathrm{K}, \mathrm{Ca}, \mathrm{Mg}, \mathrm{S}$ ) of organo-mineral fertilizers were determined according to Alcarde (2009). The microbial biomass carbon (C - mic) was determined according to Vance et al. (1987). The chemical attributes of the organo-mineral fertilizers obtained were compared to the precomposted manure to verify the possible gains or losses of the evaluated nutrients. The obtained data were submitted to analysis of variance by Test $F$. The averages were compared by the scott-Knott test ( $p<0.05$ )

\section{Results and discussion}

The earthworm fresh mass did not show the interaction between factors evaluated (Table 3). The presence of sources of phosphorus decreased the earthworm fresh mass, especially the ammonium single superphosphate source. This source of phosphorus is rich in acids and salts. Kiehl (2008) reports that such conditions lead to dehydration due to cellular plasmolysis, making it difficult to establish earthworms. Thus, the use of $23 \%$ of ammonium single superphosphate should not be indicated for vermicompost processes.

It was observed the interaction between the microbial biomass carbon ( $\mathrm{C}$ - mic) and the factors studied. The combination of composting with Itafós natural phosphate provided the highest C- mic value (Table 4). Regardless of the incorporation method, the addition of ammonium single superphosphate decreased the biomass, represented by the microbial carbon present in the organo-mineral fertilizers obtained.

The microbial biomass of the soil is considered the living part of the organic matter, constituted mainly by fungi and bacteria (Kaschuk et al., 2010). Possibly, the Itafós natural phosphate potentiated the environment for the proliferation and activity of these microorganisms, while the Ammonium single superphosphate prejudice it due to acidity and salinity.

The highest proportion of microbial biomass during the composting process in 
Table 3. Earthworm fresh mass in vermicompost processes with phosphorus sources.

\begin{tabular}{|c|c|c|c|}
\hline \multirow{2}{*}{ Treatment } & \multicolumn{3}{|c|}{ Earthworm fresh mass (g) } \\
\hline & VPB & VPE & Average \\
\hline Ammonium single superphosphate & 197.0 & 352.0 & $274.5 b$ \\
\hline Itapós natural phosphate & 313.0 & 363.0 & $338.0 \mathrm{a}$ \\
\hline Araxá natural phosphate & 354.0 & 386.0 & $370.0 \mathrm{a}$ \\
\hline Yoorin thermophosphate & 312.0 & 359.0 & $3335.5 a$ \\
\hline Average & $294.0 \mathrm{~B}$ & $365.0 \mathrm{~A}$ & $C V \%=22.6$ \\
\hline F test & $\mathrm{F}_{\text {Psource }}=2.8^{\mathrm{nt*} *}$ & $\mathrm{~F}_{\text {management }=9.1^{*}}$ & $\mathrm{~F}_{\text {interaction }}=1.4 \mathrm{~ns}$ \\
\hline
\end{tabular}

Table 4. Microbial Biomass Carbon ( $\mathrm{C}$ - mic) in organo-mineral fertilizers obtained by vermicomposting and composting and the addition of phosphorus sources.

\begin{tabular}{|c|c|c|c|c|}
\hline \multirow{2}{*}{ Treatment } & \multicolumn{4}{|c|}{$\mathrm{C}$ - mic $\mathrm{mg} \mathrm{kg}^{-1}$} \\
\hline & VPB & VPE & $\mathrm{CP}$ & Average \\
\hline Ammonium single superphosphate & $125,9 \mathrm{dA}$ & $206,7 \mathrm{dA}$ & $125,0 \mathrm{bA}$ & 152,6 \\
\hline Itapós natural phosphate & $750,2 \mathrm{aB}$ & $642,9 \mathrm{aB}$ & $952,2 \mathrm{aA}$ & 781,8 \\
\hline Araxá natural phosphate & $535,0 \mathrm{bB}$ & $385,2 \mathrm{CB}$ & $808,6 \mathrm{aA}$ & 576,3 \\
\hline Yoorin thermophosphate & $350,8 \mathrm{CB}$ & $463,0 \mathrm{bB}$ & $842,3 \mathrm{aA}$ & 552,0 \\
\hline Average & 440,5 & 424,4 & 682,0 & $C V=24,71$ \\
\hline F test & $F_{\text {Psource }}=63,3^{* *}$ & $F_{\text {management }}=25,6^{* *}$ & $\mathrm{~F}_{\text {interaction }=5,7^{\text {***}}}$ & \\
\hline
\end{tabular}

VPB - Vermicompost produced adding the P sources at the beginning of the vermicomposting process; VPE - Vermicompost produced adding the P sources at the end of the vermicomposting process. CP - Compound, non-vermicomposting, produced with the addition of the P sources at the beginning of the composting process. Average values sharing the same letter, upper case in the line and lower case in the column, do not differ by Scott-Knott test at $5 \%$.

relation to vermicomposting was also observed by Lascano et al. (2008). These authors highlight two phases of composting, the thermophilic one which has intense microbial action and the mesophyll one where the stabilization of the organic waste in a gradual way occurs, with high microbial biomass in the composting process, compared to the vermicomposting process. Microbial biomass stores a small amount of $P$, however, it has high nutrient recycling dynamics (Khan \& Joergensen, 2009).

The carbon, organic matter, and, nitrogen contents and $\mathrm{C}: \mathrm{N}$ ratio were affected by the interaction of phosphorus sources with the incorporation method (Table 5). The association of ammonium single superphosphate with vermicomposting provided the highest carbon, organic matter, and nitrogen content.

The action of microorganisms and earthworms, as a result of composting and vermicomposting, caused a reduction in the carbon content of the pre-composted cattle manure. The initial carbon content was $13.2 \%$ (Table 1). The highestrates of carbon mineralization were provided by Yoorin thermophosphate (9.3\%). The reduction of carbon with the addition of non-acidulated sources demonstrates greater adaptation and palatability of the earthworms in association with microorganisms.

There was an interaction of the factors studied for the organic matter content. The acidified source (Ammonium single superphosphate) showed the highest OM content in the VPB, VPE, and CP treatments, indicating a lower action of earthworms and microorganisms.

The addition of ammonium single superphosphate provided the highest nitrogen content in the compounds produced (Table 5). This occurred due to this source of $P$ contains $3 \%$ nitrogen in its formulation. In addition, it is emphasized that the interaction of phosphorus with ammonium $\left(\mathrm{NH}_{4}^{+}\right)$reduces the nitrogenvolatilization losses.

Nitrogen is a very reactive element, subject to various chemical and biochemical losses, mediated by microbial activity. It was verified that the addition of ammonium single superphosphate at the end of the process of vermicomposting did not provide $\mathrm{N}$ for enough time to these transformationsoccur, so the nitrogen contents were higher in the VPE treatment. Comparing the VPE to $\mathrm{CP}$, it can be observed that the activity of the earthworms resulted in increased nitrogen losses in combination with 
ammonium single superphosphate and Itafós natural phosphate (Table 5 and Table 6).

Similar results were obtained by Fornes et al. (2012) when comparing composting, vermicomposting and composting followed by vermicomposting, in waste of tomato crop. The authors report that the loss of nitrogen occurred in higher intensity in the following order: vermicomposting> composting> composting and vermicomposting.

Decreasing in nitrogen content were observed in all source of phosphorus and incorporation methods studied (Table 6). The VPB process containing Itafós natural phosphate showed the lowest $\mathrm{N}$ losses (34.2\%) occurred, whereas for the ammonium single superphosphate $54.6 \% \mathrm{~N}$ was lost. Fornes et al. (2012), comparing the composting, vermicomposting and composting processes followed by vermicomposting, verified a reduction of $75.5 \%$ in mineral nitrogen contents after 261 days of vermicomposting and a total loss of $30 \%$ of $\mathrm{N}$ in the composting process. This may be related to the $\mathrm{N}$ leaching process during the moisturizing process of the materials.

Gomes-Brandón et al. (2013) comparing composting and vermicomposting found that the earthworms excreted $\mathrm{NH}_{4}^{+}$. Therefore, during the vermicompost process interactions between phosphorus and $\mathrm{NH}_{4}^{+}$may have occurred. This type of reactions decreases $N$ losses by volatilization, evidencing that higher $\mathrm{N}$ losses occurred by leaching.

Singh \& Suthar (2012) in a study of reutilization of products of the pharmaceutical industry associated with cattle manure verified that earthworms contribute to the $\mathrm{N}$ availability during the vermicomposting process. These annelids release various nitrogen-containing products, such as enzymes, their food excrement, and viscous substances excreted by their epidermis containing $\mathrm{N}$-rich monosaccharide macromolecules, an important strategy to avoid drying out their epidermis. However, during the processes of vermicomposting and composting the constant irrigations to maintain the moisture of these processes may have contributed to leaching of $N$, explaining the reductions of this nutrient in the VPB, VPE and CP treatments.
The C:N ratio is one of the main indications of maturation of compounds and vermicompounds. According to Edwards et al. (2011), the vermicompost is considered stable when its $\mathrm{C}: \mathrm{N}$ ratio is between 12:1 and 11:1. For the other materials, stabilization is achieved when the C:N ratio reaches values lower than 20:1 and 22:1. The ideal proportions for compounds should be between 18:1 and 14:1. All treatments met these criteria (Table 5).

It was observed the interaction between the factors for the $\mathrm{pH}$ values. The association of non-acidic sources with vermicomposting resulted in the formation of a more acidic compound (Table 7). Comparing the sources of phosphorus, the highest $\mathrm{pH}$ values were observed when Yoorin thermophosphate was used.

The reduction of $\mathrm{pH}$ in vermicompost suggests that the presence of earthworms reduces the $\mathrm{pH}$ values of the compound formed by the excretion of substances such as $\mathrm{NH}_{4}^{+}$and $\mathrm{CO}^{2}$ that influence the $\mathrm{pH}$ dynamics. Similar results were also observed by Suthar et al. (2012) and Fornes et al. (2012). Therefore, Yadav \& Garg (2011) report that the sources of organic matter and the ratio of opposing electrical charges are essential in the dynamics of the $\mathrm{pH}$ in vermicompost.

The slightly acidic pH values of the Araxá and Itafós phosphate treatments in the VPB and VPE treatment may favor the solubilization of the phosphorus present in the organo-mineral fertilizers. The highest $\mathrm{pH}$ values observed in the Yoorin phosphate treatment can be related to the high calcium content, which in this fertilizer is $20 \%$.

It was verified the interaction between the factors for the water- and citric acid- soluble phosphorus (Table 8). The combination of ammonium single superphosphate and the VPE provided the highest values of water-soluble phosphorus. However, the highest citric acidsoluble phosphorus contents were observed in the Yoorin thermophosphate associated with the VPE.

The total phosphorus content was lower in the VPB compared to the CP and VPE (Table 8). These results show that the passage of phosphate sources through the digestive tract of 
Table 5. Carbon, Organic Matter and $\mathrm{N}$ content, and $\mathrm{C}: \mathrm{H}$ ratio in organo-mineral fertilizers obtained by vermicomposting and composting and the addition of phosphorus sources.

\begin{tabular}{|c|c|c|c|c|}
\hline Treatment & VPB & VPE & $\mathrm{CP}$ & Average \\
\hline \multirow{2}{*}{ Ammonium single } & \multicolumn{4}{|c|}{ C content $-\mathrm{g} \mathrm{kg}^{-1}$} \\
\hline & $11.8 \mathrm{aB}$ & $12.8 \mathrm{aA}$ & $12.1 \mathrm{aB}$ & 12.2 \\
\hline $\begin{array}{l}\text { superphosphate } \\
\text { Itapós natural phosphate }\end{array}$ & $10.2 \mathrm{bA}$ & $10.0 \mathrm{bA}$ & $10.7 \mathrm{bA}$ & 10.3 \\
\hline Araxá natural phosphate & $10.1 \mathrm{bA}$ & $10.0 \mathrm{bA}$ & $9.9 \mathrm{cA}$ & 10.0 \\
\hline Yoorin thermophosphate & $9.3 \mathrm{cA}$ & $9.2 \mathrm{cA}$ & $9.4 \mathrm{cA}$ & 9.3 \\
\hline Average & 10.3 & 10.5 & 10.5 & $C V=4.22$ \\
\hline \multirow[t]{2}{*}{ F test } & \multicolumn{4}{|c|}{$F_{\text {Psource }=118.5^{*}} \quad F_{\text {management }=0.8 \mathrm{~ns}} \quad F_{\text {interaction }=3.2^{*}}$} \\
\hline & \multicolumn{4}{|c|}{ OM content - $\mathrm{g} \mathrm{kg}^{-1}$} \\
\hline \multirow{6}{*}{$\begin{array}{l}\text { Ammonium single } \\
\text { superphosphate } \\
\text { Itapós natural phosphate } \\
\text { Araxá natural phosphate } \\
\text { Yoorin thermophosphate } \\
\text { Average } \\
\text { Ftest }\end{array}$} & $174 \mathrm{aB}$ & $196 \mathrm{aA}$ & $182 \mathrm{aB}$ & 184 \\
\hline & $158 \mathrm{bB}$ & $154 \mathrm{bB}$ & $170 \mathrm{aA}$ & 160 \\
\hline & $158 \mathrm{bA}$ & $158 \mathrm{bA}$ & $158 \mathrm{bA}$ & 158 \\
\hline & $142 \mathrm{cA}$ & $148 \mathrm{bA}$ & $152 \mathrm{bA}$ & 147 \\
\hline & 158 & 164 & 165 & $C V=5,89$ \\
\hline & \multicolumn{4}{|c|}{$\mathrm{F}_{\text {Psource }=39.0^{* *}} \quad \mathrm{~F}_{\text {management }=3.4^{*}} \quad \mathrm{~F}_{\text {interaction }=2.8^{*}}$} \\
\hline \multirow{2}{*}{ Ammonium single } & \multicolumn{4}{|c|}{ N content $-\mathrm{g} \mathrm{kg}^{-1}$} \\
\hline & $13.8 \mathrm{aC}$ & $21.6 \mathrm{aA}$ & $18.1 \mathrm{aB}$ & 17.8 \\
\hline $\begin{array}{l}\text { superphosphate } \\
\text { Itapós natural phosphate }\end{array}$ & $10.6 \mathrm{bA}$ & $10.2 \mathrm{bA}$ & $10.8 \mathrm{bA}$ & $10.5 b$ \\
\hline Araxá natural phosphate & $10.1 \mathrm{bA}$ & $9.4 \mathrm{bA}$ & $9.2 \mathrm{cA}$ & $9.5 \mathrm{~b}$ \\
\hline Yoorin thermophosphate & $10.1 \mathrm{bA}$ & $9.9 \mathrm{bA}$ & $9.6 \mathrm{cA}$ & $9.9 \mathrm{~b}$ \\
\hline Average & 11.1 & 12.8 & 11.9 & $C V=7.23$ \\
\hline F test & \multicolumn{4}{|c|}{$F_{\text {Psource }=312.0^{*}} \quad F_{\text {management }=18.4^{*}} \quad F_{\text {interaction }=28.33^{*}}$} \\
\hline \multirow{2}{*}{ Ammonium single } & \multicolumn{4}{|c|}{ C:N ration } \\
\hline & $11.0 \mathrm{bA}$ & $7.7 \mathrm{CB}$ & $8.4 \mathrm{CB}$ & 9.0 \\
\hline $\begin{array}{l}\text { superphosphate } \\
\text { Itapós natural phosphate }\end{array}$ & $12.3 \mathrm{aB}$ & $12.2 \mathrm{bA}$ & $12.6 \mathrm{bA}$ & 12.4 \\
\hline Araxá natural phosphate & $12.8 \mathrm{aB}$ & $13.5 \mathrm{aA}$ & $13.7 \mathrm{aA}$ & 13.3 \\
\hline Yoorin thermophosphate & $11.4 \mathrm{bB}$ & $11.7 \mathrm{bB}$ & $1 \quad 12.7 \mathrm{bA}$ & 11.9 \\
\hline Average & 11.9 & 11.3 & 11.8 & $C V=7.07$ \\
\hline F test & $\mathrm{F} \quad \mathrm{F}_{\mathrm{P}_{\text {source }}=76 . *}$ & $\mathrm{~F}_{\text {management }}$ & $\mathrm{F}_{\text {interaction }=7}$ & \\
\hline
\end{tabular}

Table 6. Percentage of resulting nitrogen, in relation to pre-composed manure, due to the incorporation methods and phosphorus sources.

\begin{tabular}{|c|c|c|c|c|}
\hline Treatment & VPB & VPE & $\mathrm{CP}$ & Average \\
\hline & \multicolumn{3}{|c|}{$\mathrm{N}(\%)$} & \\
\hline Ammonium single superphosphate & $45.4 \mathrm{bC}$ & $71.1 \mathrm{aA}$ & $60.0 \mathrm{bB}$ & 58.8 \\
\hline Itapós natural phosphate & $65.8 \mathrm{aA}$ & $63.4 \mathrm{bA}$ & $67.5 \mathrm{aA}$ & 65.5 \\
\hline Araxá natural phosphate & $62.1 \mathrm{aA}$ & $58.8 \mathrm{bA}$ & $57.2 \mathrm{bA}$ & 59.4 \\
\hline Yoorin thermophosphate & $62.8 \mathrm{aA}$ & $61.9 \mathrm{bA}$ & $58.9 \mathrm{bA}$ & 61.2 \\
\hline Average & 59.0 & 63.8 & 160.9 & $C V=6.65$ \\
\hline F test & $\mathrm{F}_{\text {Psource }=8.3^{* * *}}$ & $\mathrm{~F}_{\text {management }}=7.0^{* *}$ & $\mathrm{~F}_{\text {interaction }}=15.8^{* *}$ & \\
\hline
\end{tabular}

earthworms reduced the amount of phosphorus in the organo-mineral fertilizers produced. Losses due to leaching of phosphorus are rare and due to the lining with plastic tarpaulin, this reason for the decrease is unlikely.

According to Pereira (1997), the body of an earthworm has 0.6 to $1 \%$ of phosphorus in its dry mass. The average fresh mass of the earthworms in the VPB was $294 \mathrm{~g}$. Considering that $1 \%$ of the earthworm mass in the VPB treatment was phosphorus, thus $2.94 \mathrm{~g}$ of phosphorus was removed with vermicomposting. 
Table 7. pH values in organo-mineral fertilizers obtained by vermicomposting and composting and the addition of phosphorus sources

\begin{tabular}{|c|c|c|c|c|}
\hline \multirow[t]{2}{*}{ Treatment } & \multicolumn{4}{|c|}{ pH values } \\
\hline & VPB & VPE & $\mathrm{CP}$ & Average \\
\hline Ammonium single superphosphate & $4.7 \mathrm{CC}$ & $5.5 \mathrm{dA}$ & $5.1 \mathrm{CB}$ & 5.1 \\
\hline Itapós natural phosphate & $6.8 \mathrm{bB}$ & $6.8 \mathrm{CB}$ & $7.2 \mathrm{bA}$ & 6.9 \\
\hline Araxá natural phosphate & $6.9 \mathrm{bB}$ & $6.9 \mathrm{bB}$ & $7.3 \mathrm{bA}$ & 7.1 \\
\hline Yoorin thermophosphate & $7.4 \mathrm{aC}$ & $7.7 \mathrm{aB}$ & $7 \quad 7.9 \mathrm{aA}$ & 7.7 \\
\hline Average & 6.4 & 6.7 & 66.9 & $C V=1.48$ \\
\hline F test & $\mathrm{F}_{\text {Psource }=1872.3^{* * *}}$ & $\mathrm{~F}_{\mathrm{m}}$ & $\operatorname{ment}=106.6^{* *}$ & $\mathrm{on}=23.53^{* *}$ \\
\hline
\end{tabular}

However, the difference in the total phosphorus content, in VPB, in relation to CP was $14.6 \mathrm{~g} \mathrm{~kg}^{-1}$ of vermicompost. Considering a dry mass of the VPB of $11.5 \mathrm{~kg}$, at the end of the vermicomposting process, $167.9 \mathrm{~g}$ of total phosphorus were lost compared to the CP treatment. Therefore, it is not possible to attribute the loss of phosphorus solely to the removal of the earthworms from the vermicompost. Thus, it is possible that phosphorus has been converted to forms of low availability in the vermicompost, which was not extracted by the method used.

The phosphorus losses mentioned above may be related to chemical and biological reactions. Subramaniana et al. (2010) report that a lower phosphorus recovery may occur due to reactions with organic matter and interactions with other nutrients. Therefore, leaching and volatilization of phosphorus in vermicomposting and composting processes are remote.

Busato et al. (2012), evaluating the bioavailability of Araxá natural phosphate with inoculation of phosphate solubilizing bacteria in vermicompost and found that in the vermicompost inoculated with alkaline and acid phosphatase enzymes an increase of $106 \%$ of water-soluble phosphorus content in inoculated vermicompounds, as a result of the acids produced. However, according to the authors, there was a reduction in phosphorus content in resin for inoculated and non-inoculated treatments and reduction in water-soluble phosphorus content in the non-inoculated treatment. Reductions of water-soluble phosphorus content may have occurred by interactions of organic matter with phosphorus, forming molecules of lower water solubility.

The vermicomposting with the addition of natural phosphates can minimize the intense phosphorus reactions in the soil. Pramanick et al. (2009), comparing composting and vermicomposting with the addition of natural phosphate and its release in acid soils, observed that in fertilizations with vermicompost associated with natural phosphate, the bio-solubilization of phosphorus increased and there was a gradual availability of phosphorus. The vermicompost coated the phosphorus, reducing direct reactions of this nutrient with the soil, in comparison to the composted treatments. The particles of humus coat the sesquioxide and, thus, the phosphates become protected and this coating can prevent the fixation of the $P$ in the soil (Tisdale \& Nelson, 1966).

For the percentages of water-soluble $P$ and total $P$ that remained in relation to that added at the beginning of the experiment, there was no interaction of the factors evaluated (Table 9). It was not observed the difference between the incorporation processes related to vermicomposting and composting for watersoluble P content (Table 9).

The initial water-soluble $\mathrm{P}$ content of the acidified source (Ammonium single superphosphate) in the VPB, VPE and CP treatment was $1020 \mathrm{~g} \mathrm{~kg}^{-1}$. Over the experiment, $642.6 \mathrm{~g} \mathrm{~kg}^{-1}$ was lost, equivalent to $63 \%$ of the initial $\mathrm{P}$ content. Yoorin thermophosphate provided the highest percentage recovery of watersoluble P content (12006.5\%) (Table 9). This high percentage is due to Yoorin thermophosphate is insoluble in water and any increase in its solubility is highly significant for this source. Among the natural phosphates, the Araxá natural phosphate differed from the Itafós natural phosphate. It was added $60 \mathrm{~g} \mathrm{~kg}^{-1}$ of water-soluble $\mathrm{P}$ at the 
Tabela 8. Water-soluble phosphorus, citric acid-soluble phosphorus and total $\mathrm{P}$ in organo-mineral fertilizers obtained by vermicomposting and composting and the addition of phosphorus sources.

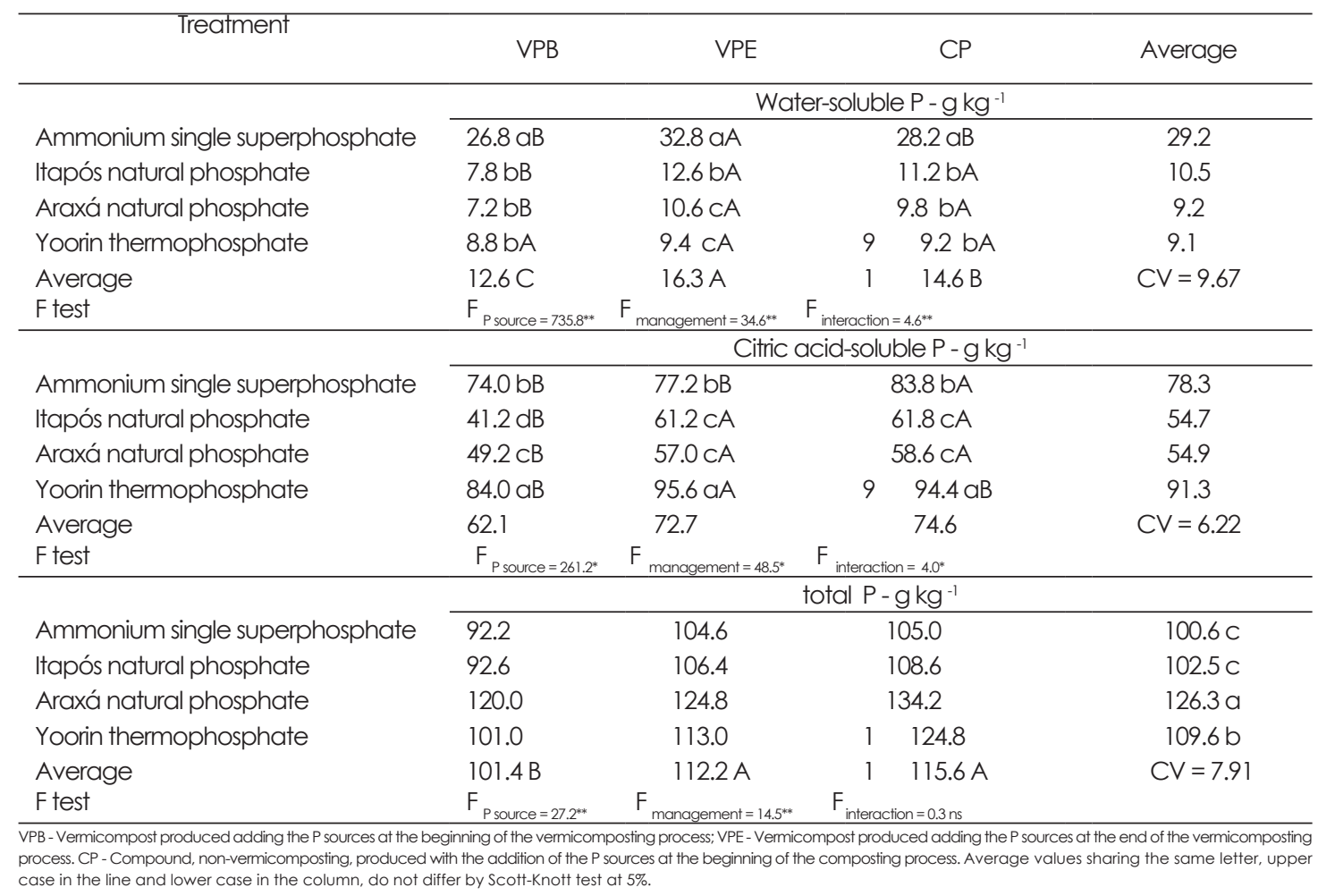

beginning part of the experiment using the Araxá natural phosphate. Over the study, an average increase of $61.2 \mathrm{~g} \mathrm{~kg}^{-1}$ resulting in a final content of $121.2 \mathrm{~g} \mathrm{~kg}^{-1}$ of water-soluble P was observed. This value is equivalent to an increase of $102 \%$, differing from the Itafós natural phosphates and ammonium single superphosphate.

The combination of Araxá's natural phosphate with composting or vermicompost with the addition of sources at the end of the process showed the highest recovery percentages of citric acid-soluble $P$ and total $P$, with values varying from $131.4 \%$ to $534.7 \%$ (Table 9). Pramanick et al. (2009) report that the addition of natural phosphates after the vermicomposting process produces an organic fertilizer with high agronomic efficiency due to the association between humus and phosphorus. This allows phosphorus to remain protected and available for a long time, and that microorganisms and organic acids originating from organic matter raise the solubility of natural phosphates. The earthworms during the vermicomposting process ingest the organic material reducing the organic carbon contents and raising the concentration of nutrients, however, the main mechanism for solubilization of insoluble phosphorus is the excretion of organic acids promoted by microorganisms (Pramanick, 2010).

The addition of phosphorus sources at the beginning of vermicomposting provided the lowest percentages of citric acid-soluble P (Table 9). This phosphorus reduction may have occurred as a result of the passage of phosphorus sources through the intestinal tract of the earthworm. Therefore, the function of earthworms is essentially related to the physical and biological structuring of the organic substrate, allowing favorable conditions for colonization of microorganisms that contribute to the solubilization of natural phosphates (Wang et al., 2013). It should be noted that the vermicomposting process will be efficient when phosphorus sources are used at the end of the process, without the presence of earthworms, thus there will be the microorganisms action only, as verified in the VPE treatment (Table 9).

It was observed an interaction of the factors studied for the sulfur content (Table 10). The highest sulfur contents were provided by the addition of ammonium single superphosphate at the end of the vermicomposting process (VPF).

Subramaniana et al. (2010), in studies of 
Table 9. Water-soluble phosphorus, citric acid-soluble phosphorus and total $\mathrm{P}$ in relation to pre-composed manure, due to the incorporation methods and phosphorus sources.

\begin{tabular}{|c|c|c|c|c|}
\hline Treatment & VPB & VPE & $\mathrm{CP}$ & Average \\
\hline & \multicolumn{4}{|c|}{ Water-soluble P (\%) } \\
\hline Ammonium single superphosphate & 33.8 & 41.4 & 35.9 & $37.0 \mathrm{~d}$ \\
\hline Itapós natural phosphate & 81.6 & 131.2 & 117.9 & $110.2 \mathrm{c}$ \\
\hline Araxá natural phosphate & 157.1 & 234.0 & 214.9 & $202.0 \mathrm{~b}$ \\
\hline Yoorin thermophosphate & 11606.8 & 12415.9 & 11997.0 & $12006.5 \mathrm{a}$ \\
\hline Average & $2969.8 \mathrm{a}$ & $3205.6 a$ & $13091.4 a$ & $C V=22.79$ \\
\hline \multirow[t]{2}{*}{ F test } & $F_{\text {P source }=1070.2^{* * *}}$ & $\mathrm{~F}_{\text {management }=0.5 \mathrm{~ns}}$ & $\mathrm{~F}_{\text {interection }}=0.3 \mathrm{~ns}$ & \\
\hline & \multicolumn{4}{|c|}{ Citric acid-soluble P (\%) } \\
\hline Ammonium single superphosphate & $97.4 \mathrm{CA}$ & $101.8 \mathrm{dA}$ & $111.3 \mathrm{cA}$ & 103.5 \\
\hline Itapós natural phosphate & $192.9 \mathrm{bB}$ & $284.6 \mathrm{bA}$ & $290.8 \mathrm{bA}$ & 256.1 \\
\hline Araxá natural phosphate & $447.1 \mathrm{aB}$ & $524.4 \mathrm{aA}$ & $534.7 \mathrm{aA}$ & 502.1 \\
\hline Yoorin thermophosphate & $115.3 \mathrm{cA}$ & $131.1 \mathrm{cA}$ & $128.1 \mathrm{cA}$ & 124.8 \\
\hline Average & 213.2 & 260.5 & 266.2 & $C V=7.38$ \\
\hline \multirow[t]{2}{*}{ F test } & \multirow{2}{*}{\multicolumn{4}{|c|}{$\mathrm{F}_{\text {management }}=51.0^{0 * *}$}} \\
\hline & & & & \\
\hline \multirow{6}{*}{$\begin{array}{l}\text { Ammonium single superphosphate } \\
\text { Itapós natural phosphate } \\
\text { Araxá natural phosphate } \\
\text { Yoorin thermophosphate } \\
\text { Average } \\
\text { F test }\end{array}$} & 70.3 & 80.5 & 78.6 & $76.4 \mathrm{C}$ \\
\hline & 88.5 & 96.7 & 100.4 & $95.2 \mathrm{~b}$ \\
\hline & 126.5 & 131.4 & 142.1 & $133.3 \mathrm{a}$ \\
\hline & 92.7 & 97.5 & $1 \quad 105.4$ & 98.5 b \\
\hline & $94.5 \mathrm{C}$ & $101.5 \mathrm{~B}$ & $1 \quad 106.6 \mathrm{~A}$ & $C V=7.58$ \\
\hline & $F_{\text {Psource }=144.0^{* *}}$ & $F_{\text {management }=12.6^{* *}}$ & $F_{\text {interaction }=0.6 \mathrm{~ns}}$ & \\
\hline
\end{tabular}

Table 10. Sulfur content in organo-mineral fertilizers obtained by vermicomposting and composting and the addition of phosphorus sources.

\begin{tabular}{|c|c|c|c|c|}
\hline \multirow[t]{2}{*}{ Treatment } & \multicolumn{4}{|c|}{ S content $\mathrm{g} \mathrm{kg}^{-1}$} \\
\hline & VPB & VPE & $\mathrm{CP}$ & Average \\
\hline Ammonium single superphosphate & $24.2 \mathrm{aC}$ & $30.8 \mathrm{aA}$ & $28.0 \mathrm{aB}$ & 27.7 \\
\hline Itapós natural phosphate & $1.8 \mathrm{bA}$ & $3.2 \mathrm{aB}$ & $2.3 \mathrm{bA}$ & 2.49 \\
\hline Araxá natural phosphate & $1.2 \mathrm{bA}$ & $1.8 \mathrm{bA}$ & $1.4 \mathrm{bA}$ & 1.54 \\
\hline Yoorin thermophosphate & $1.5 \mathrm{bA}$ & $1.4 \mathrm{aB}$ & $11.5 \mathrm{bA}$ & 51.46 \\
\hline Average & 7.2 & 9.3 & 88.3 & $C V=16.95$ \\
\hline F test & $\mathrm{F}_{\text {Psource } 1270.1^{*}}$ & $\mathrm{~F}_{\text {management }=11.5^{*}}$ & $F F_{\text {interaction }=60^{*}}$ & \\
\hline
\end{tabular}

composting and vermicomposting with waste cassava, cattle, and poultry manures, the authors verified that the composting process increased the sulfur content whereas the vermicomposting decreased it. After 45 days of vermicomposting, the treatment of the same proportion of waste cassava, cattle, and poultry manures decreased the sulfur content from $78 \mathrm{mg} \mathrm{kg}^{-1}$ to $53 \mathrm{mg} \mathrm{kg}^{-1}$. This sulfur decreasing may be due to the action of earthworms and microorganisms.

It was observed an interaction of the factors evaluated for the percentage of sulfur (Table 11). The addition of the Itafós natural phosphorus at the end of the vermicomposting process (VPE) and composting (CP) increased the sulfur content by $179 \%$ and $130.4 \%$, respectively. The phosphorus sources used in the experiment have $S$ in their constitution, explaining the highest $S$ contents in the VPE treatment, except for the Yoorin thermophosphate. The VPB process decreased the $S$ contents in all sources, except for the Yoorin thermophosphate.

The vermicomposting can lead to a loss of $88 \%$ in the $S$ content, while the composting adds around $4.2 \%$ (Fornes et al., 2012). The higher availability of sulfur in composting is related to the intense microbial activity (Subramaniana et al., 2010). 
Guimarães et al. (2017) / Production of phosphate biofertilizer ...

Table 11.Percentage of Sulfur in relation to pre-composed manure, due to the incorporation methods and phosphorus sources.

\begin{tabular}{lcccc}
\hline \multicolumn{1}{c}{ Treatment } & VPB & VPE & CP & Average \\
\hline & \multicolumn{4}{c}{ Percentage of S } \\
\cline { 2 - 4 } Ammonium single superphosphate & $61.8 \mathrm{CA}$ & $78.9 \mathrm{cA}$ & $72.3 \mathrm{bA}$ & 71.0 \\
Itapós natural phosphate & $101.3 \mathrm{aC}$ & $179.3 \mathrm{aA}$ & $130.4 \mathrm{aB}$ & 137.0 \\
Araxá natural phosphate & $69.7 \mathrm{CB}$ & $102.6 \mathrm{bA}$ & $81.1 \mathrm{bB}$ & 84.5 \\
Yoorin thermophosphate & $82.3 \mathrm{bA}$ & $76.9 \mathrm{CA}$ & $81.5 \mathrm{bA}$ & 80.2 \\
Average & 78.8 & 109.4 & 91.3 & $\mathrm{CV}=14.42$ \\
F test & $\mathrm{F}_{\text {Psource }=73.4^{* *}}$ & $\mathrm{~F}_{\text {management }=6.3^{* *}} \mathrm{~F}_{\text {interaction }=8.9^{* * *}}$ & \\
\hline
\end{tabular}

VPB - Vermicompost produced adding the P sources at the beginning of the vermicomposting process; VPE - Vermicompost produced adding the P sources at the end of the vermicomposting process. CP-Compound, non-vermicomposting, produced with the addition of the P sources at the beginning of the composting process. Average values sharing the same letter, upper case in the line and lower case in the column, do not differ by Scott-Knott test at $5 \%$.

The potassium contents present in the organo-mineral fertilizers were influenced by the phosphorus sources and incorporation method, independently (Table 12), highlighting the Itafós natural phosphate and the composting process.
Similar results were obtained by Fornes et al. (2012), who reported an increase in potassium contents after the stabilization of the composting process, and losses of $\mathrm{K}$ in the vermicomposting process were related to leaching.

Table 12. Potassium, Calcium and Magnesium contents in organo-mineral fertilizers obtained by vermicomposting and composting and the addition of phosphorus sources.

\begin{tabular}{|c|c|c|c|c|}
\hline \multirow{3}{*}{$\begin{array}{l}\text { Ammonium single superphosphate } \\
\text { Itapós natural phosphate }\end{array}$} & \multicolumn{4}{|c|}{ K content - $\mathrm{g} \mathrm{kg}^{-1}$} \\
\hline & 6.1 & 5.3 & 8.0 & $6.5 b$ \\
\hline & 6.4 & 5.9 & 9.2 & $7.2 \mathrm{a}$ \\
\hline Araxá natural phosphate & 5.1 & 5.3 & 7.6 & $6.0 c$ \\
\hline Yoorin thermophosphate & 5.6 & 5.8 & 8.6 & $6.6 b$ \\
\hline Average & $5.8 \mathrm{~B}$ & $5.6 \mathrm{~B}$ & $8.3 \mathrm{~A}$ & $C V=7.2$ \\
\hline \multirow[t]{2}{*}{ F test } & $\mathrm{F}_{\text {Psource }}=*$ & $F_{\text {management }}=203.8^{*}$ & $F_{\text {interaction }}=2.075 \mathrm{~ns}$ & \\
\hline & \multicolumn{4}{|c|}{ Mg content - $\mathrm{g} \mathrm{kg}^{-1}$} \\
\hline Ammonium single superphosphate & $2.2 \mathrm{CB}$ & $3.3 \mathrm{aA}$ & $3.1 \mathrm{aA}$ & 2.9 \\
\hline Itapós natural phosphate & $2.6 \mathrm{bA}$ & $2.6 \mathrm{bA}$ & $2.7 \mathrm{bA}$ & 2.7 \\
\hline Araxá natural phosphate & $3.7 \mathrm{aA}$ & $3.3 \mathrm{aB}$ & $3.3 \mathrm{aB}$ & 3.4 \\
\hline Yoorin thermophosphate & $2.5 \mathrm{bA}$ & $2.6 \mathrm{bA}$ & $2.8 \mathrm{bA}$ & 2.6 \\
\hline Average & 2.8 & 2.9 & 2.9 & $C V=7.25$ \\
\hline \multirow[t]{2}{*}{ F test } & \multicolumn{4}{|c|}{$\mathrm{F}_{\text {management }=5.19^{*}} \quad \mathrm{~F}_{\text {interaction }=12.0^{*}}$} \\
\hline & \multicolumn{4}{|c|}{ Ca content $-\mathrm{g} \mathrm{kg}^{-1}$} \\
\hline Ammonium single superphosphate & $64.0 \mathrm{bB}$ & $75.0 \mathrm{bA}$ & $66.2 \mathrm{bB}$ & 68.4 \\
\hline Itapós natural phosphate & $60.8 \mathrm{bA}$ & $60.2 \mathrm{cA}$ & $60.8 \mathrm{cA}$ & 60.6 \\
\hline Araxá natural phosphate & $104.6 \mathrm{aB}$ & $108.2 \mathrm{aB}$ & $124.6 \mathrm{aA}$ & 112.4 \\
\hline Yoorin thermophosphate & $49.6 \mathrm{CB}$ & $51.8 \mathrm{~dB}$ & $58.0 \mathrm{cA}$ & 53.1 \\
\hline Average & 69.7 & 73.8 & 77.4 & $C V=5.28$ \\
\hline F test & $F_{\text {Psource }=702.2^{* *}}$ & $\mathrm{~F}_{\text {management }=19.3^{* *}}$ & eraction $=11.8^{* *}$ & \\
\hline
\end{tabular}

VPB - Vermicompost produced adding the P sources at the beginning of the vermicomposting process; VPE - Vermicompost produced adding the P sources at the end of the vermicomposting process. CP - Compound, non-vermicomposting, produced with the addition of the P sources at the beginning of the composting process. Average values sharing the same letter, upper case in the line and lower case in the column, do not differ by Scott-Knott test at $5 \%$.

The interaction of phosphorus sources and incorporation methods altered the calcium and magnesium contents in the organo-mineral fertilizers produced (Table 12). The association of composting with Araxá natural phosphate provided the highest calcium content and the worst performance in the addition of Yoorin thermophosphate at the beginning of vermicomposting. However, the addition of the phosphate source at the beginning of the vermicompost provided higher magnesium contents, especially the Araxá's natural phosphate, comparing to the ammonium single superphosphate (Table 12).

Araxá phosphate has 23 to $27 \%$ calcium in its constitution, a factor that contributed to its better results comparing to the ammonium single superphosphate (14 to 19\%) (Khiel, 2008), Itafós natural phosphate (13\%) and Yoorin thermophosphate $(20 \% \mathrm{Ca})$.

The highest calcium content in the composting process can be related 
to the efficient action and adaptation of microorganisms to calcium mineralization. Deka et al. (2011), comparing the composting and vermicomposting processes with plant residues and cattle manure, obtained similar results, observing increases calcium contents obtained during the composting process and a decrease during vermicomposting. During the vermicomposting process, calcium assimilation by the earthworms or leaching can lead to calcium decreasing in the vermicompost (Suthar \& Singh, 2008). In addition, Kiehl (2008) reports that water-soluble phosphate fertilizers, when reacted with free or combinable calcium, may become insoluble. This phenomenon is called retrogradation, reducing the agronomic efficiency of organo-minerals. It was observed the interaction between the factors evaluated for the percentage of calcium resulting in relation to pre-composed manure (Table 13). The addition of Araxá natural phosphate in composting (CP) provided an increase of $8.5 \%$ in calcium content. However, the addition of thermophosphate Yoorin at the beginning of vermicomposting caused a loss of $51.8 \%$ in Ca content.

The humic substances generated during the decomposition of organic matter are able to adsorb calcium ions and produce new acidic substances that may contribute to the solubilization of phosphorus from natural phosphates (Singh \& Amberger, 1990).

Table 13. Percentage of calcium in relation to pre-composed manure, due to the incorporation methods and phosphorus sources.

\begin{tabular}{|c|c|c|c|c|}
\hline Treatment & VPB & VPE & $\mathrm{CP}$ & Average \\
\hline \multicolumn{5}{|c|}{ Calcium (\%) } \\
\hline Ammonium single superphosphate & $68,0 \mathrm{bB}$ & $79,9 \mathrm{CA}$ & $71,1 \mathrm{CB}$ & 73,0 \\
\hline Itapós natural phosphate & $88,1 \mathrm{aA}$ & $86,8 \mathrm{bA}$ & $88,6 \mathrm{bA}$ & 87,8 \\
\hline Araxá natural phosphate & $90,6 \mathrm{aB}$ & $94,9 \mathrm{aB}$ & $108,5 a A$ & 98,0 \\
\hline Yoorin thermophosphate & $49,2 \mathrm{CB}$ & $51,3 \mathrm{~dB}$ & $56,8 \mathrm{dA}$ & 52,4 \\
\hline Average & 74,0 & 78,2 & 81,2 & $C V=5,36$ \\
\hline F test & fonte de $\mathrm{P}=337$, & $15,2^{* *} \quad \mathrm{~F}_{\text {int }}$ & & \\
\hline
\end{tabular}

VPB - Vermicompost produced adding the P sources at the beginning of the vermicomposting process; VPE - Vermicompost produced adding the P sources at the end of the vermicomposting process. CP - Compound, non-vermicomposting, produced with the addition of the P sources at the beginning of the composting process. Average values sharing the same letter, upper case in the line and lower case in the column, do not differ by Scott-Knott test at $5 \%$.

\section{Conclusion}

The addition of Araxá or Itafós natural phosphate in composting or after vermicomposting process leads to the production of an organo-mineral fertilizer with good availability of nutrients, such as calcium and phosphorus.

\section{References}

Alcarde, J.C. 2009. Manual de análise de fertilizantes. FEALQ, Piracicaba, Brasil. 259 p.

Busato, J.G., Lima, L.S., Aguiar, N.O., Canellas, L.P., Olivares, F.L. 2012. Changes in labile phosphorus forms during maturation of vermicompost enriched with phosphorus-solubilizing and diazotrophic bacteria. Soil Biology \& Biochemistry 110: 390-395.

Campos, A.T., Novaes, L.P., Pires, M.F.A., Campos, D.S. 2004. Instalações, ambiência e manejo dos dejetos. In: Campos, O. F. (ed.) Gado de leite: o produtor pergunta, a Embrapa responde.Brasília: Embrapa Informação Tecnológica, Brasília, Brasil. p. 220-239.
Carvalho, R.P.; Moreira, R.A.; Da Cruz, M.C.M.; Oliveira, A. F.; Fagundes, M.C.P. 2015. Comportamento nutricional de oliveiras com a aplicação de fertilizante organo-mineral. Comunicata Scientiae 6: 224-233.

Deka, H., Deka, S., Baruah, C.K., Das, J., Hoque, S., Sarma, N.S. 2011 . Vermicomposting of distillation waste of citronella plant (Cymbopogon winterianus Jowitt.) employing Eudrilus eugeniae. Bioresource Technology 102: 6944-6950.

Edwards, C.A., Subler, E., Arancon, N.Q. 2011. Vermiculture technology: earthworms, organic wastes, and environmental. In: Edwards, C.A., Arancon, N.Q. (eds.) Quality criteria for vermicompost. Taylor and Francis, Boca Ranton, USA. p. 288-299.

Fornes, F., Mendoza-Hernández, D., Garcia-De-LaFuente, R., Abad, M., Belda, R. 2012. Composting versus vermicomposting: a comparative study of organic matter evolution through straight and combined processes. Bioresource Technology 118: 296-305.

Gómez-Brandón, M.; Lores, M.; Domíngues, J. 2013. Changes in chemical and microbiological 
properties of rabbit manure in a continuousfeeding vermicomposting system. Bioresource Technology 128: 310-316.

Kaschuk, G.; Alberton, O.; Hungria, M. 2010. Three decades of soil microbial biomass studies in Brazilian ecosystems: lessons learned about soil quality and indications for improving sustainability. Soil Biology and Biochemistry 42: 1-13.

Khan, S. K.; Joergensen, R. G. 2009. Changes in microbial biomass and $P$ fractions in biogenic household waste compost amended with inorganic $P$ fertilizers. Bioresource Technology 100: 303-309

Kiehl, E.J. 2008. Fertilizantes organominerais. Ceres, Piracicaba, Brasil. 160 p.

Lascano, C., Gómez-Brandón, M., Domíngues, J. 2008. Comparison of the effectiveness of composting and vermicomposting for the biological stabilization of cattle manure. Chemosphere 72: 1013-1019.

Pereira, J.E. 1997. Minhocas: manual prático sobre minhocultura. Nobel, São Paulo. 28 p.

Pramanick, P. 2010. Changes in microbial properties and nutrient dynamics in bagasse and coir during vermicomposting: Quantification of fungal biomass through ergosterol estimation in vermicompost. Waste Management 30: 787-79.

Pramanick, P., Bhattacharya, S., Bhattacharyya, P., Banick, P. 2009. Phosphorous solubilization from rock phosphate in presence of vermicomposts in Aqualfs. Geoderma 152: 16-22.

Singh, C.P., Amberger, A. 1990. Humic substances in straw compost with rock phosphate. Biological Wastes 31: 165-174.

Singh, D., Suthar, S. 2012. Vermicomposting of herbal pharmaceutical industry solid wastes. Ecological Engineering 39: 1-6.

Souza, R. F.; Faquin, V.; Andrade, A. T.; Torres, P. R. F. 2007 Formas de fósforo em solos sob influência da calagem e adubação orgânica. Revista Brasileira de Ciências do Solo, 31: 1535-1544.

Subramaniana, S., Sivarajanb, M., Saravanapriyaa, S. 2010. Chemical changes during vermicomposting of sago industry solid wastes. Journal of Hazardous Materials 179: 318322.

Suthar, S., Mutiyar, P.K., Sing, S. 2012. Vermicomposting of milk processing industry sludge spiked with plant wastes. Bioresource Technology 116: 214-219.

Suthar, S. 2010. Pilot-scale vermireactors for sewage sludge stabilization and metal remediation process: comparison with smallscale vermireactors. Ecological Engineering 36: 703-712.

Suthar , S.; Singh, S. 2008. Feasibility of vermicomposting in biostabilization sludge from a distillery industry. Science of the Total Environment 394: 237-243.

Tisdale, S.L., Nelson, W.L. 1966. Soil fertility and fertilizers. 2.ed. Macmilian, Nova Iorque, Estados Unidos. $694 \mathrm{p}$.

Vance, E.D., Brookes, P.C., Jenkinson, D.S. 1987. An extraction method for measuring soil microbial biomass-C. Soil Biology \& Biochemistry 19: 703707.

Yadav, A., Garg, V.K. 2011 . Recycling of organic wastes by employing Eisenia fetida. Bioresource Technology 102: 2874-2880.

Wang, L., Zheng, Z., Zhang, Y., Chao, J., Gao, Y., Luo, X., Zhang, J. 2013. Biostabilization enhancement of heavy metals during the vermiremediation of sewage sludge with passivant. Journal of Hazardous Materials 244245: 1-9. 